\title{
DINAMIKA RELASI DAN KUASA NEGARA DALAM PRODUKSI KONTEN DI MEDIA SIBER PEMERINTAH MENJELANG PEMILIHAN UMUM PRESIDEN 2019
}

\section{THE DYNAMICS OF STATE RELATION AND POWER IN GOVERNMENT ONLINE MEDIA CONTENT PRODUCTION TOWARDS THE 2019 INDONESIA PRESIDENTAL GENERAL ELECTION}

\author{
Siap Bangun Negara ${ }^{1}$, Udi Rusadi ${ }^{2}$ \\ ${ }^{1}$ Direktorat Pengelolaan Media Kementerian Komunikasi dan Informatika RI \\ Jalan Medan Merdeka Barat No.9, Jakarta 10110, Indonesia \\ ${ }^{2}$ Institut Ilmu Sosial dan Ilmu Politik Jakarta \\ Jalan Lenteng Agung Raya No.32, Jakarta 12610, Indonesia \\ 1'siaptopskor@gmail.com; ${ }^{2}$ firusadi51@gmail.com \\ Diterima tgl. 15/8/2019; Direvisi tgl. 29/5/2020; Disetujui tgl. 2/6/2020
}

\begin{abstract}
This study aims to describe the dynamics of state power in producing political and economic content at www.indonesiabaik.id cyber media prior to the 2019 Presidential Election. This study uses the constructivism paradigm with a qualitative approach and case study methods. Two informants were selected purposively. The validity of data was using source triangulation techniques. The data collective techniques were through interviews, observations, and library studies. The result shows that the Indonesian government intervenes and puts pressure on editors in the news productions in a hard campaign way style. In terms of power relations, the role of government cyber media was to create an open space for public opinion creation through dialogues.
\end{abstract}

Keywords: Power Relations, Government Framing, Presidential Election.

\section{ABSTRAK}

Penelitian ini bertujuan mendeskripsikan dinamika kuasa negara dalam produksi konten politik dan ekonomi di media siber www.indonesiabaik.id selama Pemilihan Umum Presiden 2019. Penelitian ini menggunakan paradigma konstruktivisme dengan pendekatan kualitatif dan metode studi kasus. Informan berjumlah dua orang yang dipilih secara purposif. Uji keabsahan data dilakukan melalui teknik triangulasi sumber. Teknik pengumpulan data dilakukan melalui wawancara, observasi, dan studi kepustakaan. Hasil penelitian menunjukkan cara pemerintah memproduksi konten isu politik dan ekonomi di situs ini dengan melakukan intervensi dan memberi tekanan kepada editor untuk membuat konten bermuatan hard campaign. Peran media siber ini dalam relasi kuasa menjelang Pemilu Presiden 2019 yakni membuka ruang dalam membangun opini publik melalui dialog yang terbangun di dalamnya.

Kata Kunci: Relasi Kuasa, Framing Pemerintah, Pemilu Presiden.

\section{PENDAHULUAN}

\subsection{Latar Belakang dan Rumusan Masalah}

Media merupakan bagian penting dari setiap sistem politik dan sosial. Media menjadi sumber informasi, menghibur, mendidik, dan menanamkan nilai-nilai masyarakat dan mengintegrasikan mereka ke dalam sistem sosial (Herman \& Chomsky, 1988). Media menyediakan ruang untuk perdebatan dan menjadi seperangkat saluran untuk para politisi, kandidat, partai politik, kelompok kepentingan dan publik serta sarana publisitas dan pengaruh bagi para aktor-aktor politik (McQuail, 2006).

Secara prinsip, media dituntut untuk bebas dari segala pengaruh, karena media sejatinya mengabdi kepada kepentingan publik. Namun berbicara tentang independensi media, hingga saat 
ini, belum ada media yang benar-benar ideal dan bebas dari intervensi. Tidak hanya di Indonesia, bahkan di Amerika dan Eropa sekalipun terjadi fenomena serupa, di mana tekanan ekonomi dan politik pada media massa juga ada. Chomsky dan Herman (1988) menggunakan konsep The Propaganda Model dan melihat media massa di AS cenderung bergantung kepada sumber informasi yang berasal dari para elite. Juga muncul kecenderungan media turut berpartisipasi dalam kampanye propaganda yang mendukung kepentingan para elite.

Catrina (Fanani, 2016) mengatakan ada pengaruh kuat pemilik modal terhadap konten media selama masa pemilihan umum (Pemilu) 2014. Adanya afiliasi politik membuat media kesulitan memisahkan kepentingan politik dalam keputusan pemberitaan. Sebabnya, sejumlah calon presiden yang ikut dalam pemilu presiden 2014 adalah pemilik dari sebuah grup media. Contohnya, Aburizal Bakrie dengan grup Viva, Surya Paloh dengan Media Grup, dan Hari Tanoesoedibjo dengan MNC Grup-nya.

Pengaruh pemilik modal dan juga pemilik media telah mengganggu independensi dan netralitas organisasi media. Media massa mengalami tekanan ekonomi dan politik dalam penyusunan kebijakan editorialnya. Catrina (Fanani, 2016) menyebutkan karena adanya afiliasi politik, media kesulitan dalam memisahkan kepentingan politik dalam keputusan pemberitaan. Tidak hanya membiaskan fungsi media massa, intervensi pemilik modal terhadap konten media membawa dampak negatif dalam perkembangan independensi media dan membatasi gerak media.

Untuk permasalahan bias, maka tidak hanya media massa saja yang terpengaruh oleh tekanan ekonomi dan politik dalam kebijakan editorial. Bila ingin menggali lebih jauh lagi, maka proses produksi konten dan pembingkaian atas sebuah realitas disebut ikut terseret dalam bias atau prasangka serta dapat mempengaruhi opini publik. Menurut D'Angelo (2002), sarjana-sarjana kritis sering memandang opini publik dalam agregrat untuk memperlihatkan bagaimana opini publik didominasi oleh frame-frame media.

Permalasahan itu terlihat dalam penelitian Fanani (2016) terkait dengan analisis kebijakan redaksional surat kabar yang memiliki afiliasi dengan agama tertentu pada pemberitaan religiuspolitik selama masa kampanye pemilihan Presiden Republik Indonesia 2009. Tapi bagaimana dengan media yang dimiliki atau didanai oleh pemerintah?

Di satu sisi, pemerintah pasti membutuhkan legitimasi untuk tindakan mereka yang memerlukan pembenaran atas tindakan mereka secara terbuka. Pemerintah perlu menumbuhkan citra positif untuk mendapatkan keuntungan atas oposisi dan lawan-lawan politiknya, memenangkan persetujuan publik dan mendapatkan kekuatan politik dengan menggunakan media (Kohut, 2008). Sementara di sisi lain, hubungan antara pemerintah dan media tidak dapat dielakkan dalam setiap sistem politik. Di sejumlah negara, pemerintah bahkan mengelola medianya sendiri sebagai bagian dari legitimasi atas kekuasaannya. Media yang dikelola oleh pemerintah ini digunakan untuk menghadang pemberitaan media massa yang tidak terkontrol dengan menyajikan datanya sendiri (Yüksel, 2013).

Perlu diketahui bahwa pemerintah memiliki kuasa dan mencoba untuk memperkuat sirkulasi media pemberitaan dengan bingkai yang mereka sukai, serta menjangkau publik untuk mendapatkan perhatian dan dukungannya (Kriesi, 2004). Proses ini mewajibkan pemerintah menggunakan beberapa upaya terorganisir karena pemerintah tidak dapat mengandalkan pemberitaan media hanya sebagai instrumen saja. Media tidak perlu berkonsentrasi pada bagian substantif dari pesan yang diberikan oleh pejabat (pemerintah), tetapi mereka mencoba untuk menunjukkan kemandirian mereka dengan berfokus pada aspek sosial dan pribadi dari kontes politik dan pada niat strategis dari para aktor politik (McQuail, 2006).

Organisasi media sendiri menggunakan kekuatan mereka yang berasal dari pemilihan berita (fungsinya sebagai gate keeper), membingkai konten berita. Dalam pengertian ini, media tidak 
hanya memberikan informasi, tetapi juga dapat menjadi aktor otonom dalam proses politik. Dalam proses ini, hubungan media dan pemerintah dapat dipertimbangkan dalam hal perebutan kekuasaan untuk mempengaruhi agenda dan membuat kerangka mereka sendiri sebagai bagian dari cerita dalam upaya untuk mempengaruhi opini publik (McCombs, 2004).

Itu karena kekuatan media ikut berperan membentuk kekuatan sosial yang diperlukan pemerintah dalam merumuskan kebijakan publik yang menguntungkan. Untuk itu media menjadi bentuk kekuatan sosial yang muncul di ranah publik (Couldry, N., \& Curran, 2003). Kekuatan media memiliki kemampuannya sendiri untuk mengalirkan arus informasi, pengetahuan, dan visualisasi fenomena dan realitas. Selanjutnya, media memegang kekuatan tertentu untuk mempengaruhi struktur sosial, serta mengintervensi konflik sosial (kata "konflik" di sini mengambil istilah yang digunakan Giddens dalam mewakili dinamika interaksi sosial) (Pahdepie, 2014). Melalui kemampuan dalam hal media sebagai tema yang muncul dari konflik sosial, media memiliki kekuatan untuk mengedarkan kekuatan simbolis.

Untuk tujuan ini, pemerintah berusaha untuk menyebarkan strategi dalam mengkomunikasikan pesan-pesannya dibandingkan hanya mengharapkan pesan-pesannya disampaikan secara sederhana oleh media. Manajemen berita dapat digambarkan sebagai upaya strategis pemerintah untuk mempengaruhi agenda media dan upaya pembingkaiannya yang pada gilirannya menguntungkan pemerintah dalam hal opini publik melalui kuasanya dalam media (Kohut, 2008).

Relasi kekuasaan juga yang sekarang ini tengah menjadi fokus penelitian, di mana pemerintah dengan kekuasaannya mampu menjadikan media sebagai alat dalam membangun realitas. Berita dalam media massa dihasilkan bukan hanya menggambarkan realitas, tetapi juga merupakan hasil dari konstruksi media itu sendiri. Media massa dipandang sebagai agen konstruksi yang mendefinisikan realitas. Lewat berbagai instrumen yang dimilikinya, media ikut membentuk realitas yang tersaji dalam pemberitaan. Fakta yang terkandung didalamnya sudah mengalami penyaringan karena media massa dianggap mampu menkonstruksikan realitas sosial (Eriyanto, 2008). Ditambahkan bahwa media massa bukanlah sekedar alat untuk menyalurkan pesan saja, didalamnya ia juga subjek yang mengkonstruksi realitas, lengkap dengan pandangan, bias, dan pemihakannya.

Relasi kekuasaan juga yang sekarang ini tengah menjadi fokus penelitian yang tengah peneliti lakukan. Pemerintah Indonesia melalui situs indonesiabaik.id ditenggarai menjadikan media siber ini lebih banyak memperlihatkan berbagai pencapaian-pencapaian kerja pemerintah. Situs ini sendiri berdiri dan hadir sebagai salah satu program Kementerian Komunikasi dan Informatika di bidang "Government Public Relations" mulai 2015. Situs yang baru diluncurkan ke publik pada 2017 ini menginformasikan kinerja serta berbagai capaian dan mensosialisasikan program-program pemerintah dalam bentuk infografis dan video grafis.

Untuk komposisi sumber daya manusia (SDM)-nya, indonesiabaik.id sebagian berasal dari pegawai negeri sipil (PNS) Subdit Audio Visual dan Media Sosial (AVMS) Direktorat Pengelolaan Media (Dit. PM) Ditjen Informasi dan Komunikasi Publik (IKP) Kementerian Komunikasi dan Informatika RI. Kemudian sebagian SDM lagi berasal dari pegawai kontrak pemerintah yang dipekerjakan oleh Subdit AVMS Dit.PM dengan komposisi tenaga ahli, copywriter, pekerja desain grafis dan video grafis, pustakawan, serta social media officer.

Perlu diketahui bahwa Government Public Relations (GPR) merupakan program prioritas untuk memastikan masyarakat mengetahui apa yang dilakukan pemerintah dan berpartisipasi dalam pembangunan. Implementasi GPR dilaksanakan sesuai dengan Instruksi Presiden Nomor 9 Tahun 2015 tentang Pengelolaan Komunikasi Publik. Basis kerja Government Public Relations adalah pengelolaan informasi dan komunikasi yang berkelanjutan untuk memperoleh pemahaman dan dukungan publik terhadap Program dan Kebijakan Pemerintah. 
Sebagai media milik pemerintah, tentu indonesiabaik.id akan selalu dihakimi hingga dinilai menyajikan informasi-informasi yang lebih berpihak terhadap pemerintah. Dalam pengamatan penulis, situs ini memberi porsi lebih banyak dalam mempublikasikan pencapaian-pencapaian yang dinilai penting untuk diinformasikan sebagai hasil dari kinerja pemerintah. Menteri Komunikasi dan Informatika (Menkominfo) 2014-2019, Rudiantara, mengingatkan semua staf hubungan masyarakat (Humas) Pemerintah untuk meningkatkan peran strategis Government Public Relation (GPR) dalam mensosialisasikan gerakan nasional revolusi mental (Kominfo.go.id, 2017). Dengan berfungsinya GPR, lanjut Menkominfo, akan dapat dihilangkan ego sektoral. Sehingga nantinya akan ada sinkronisasi dalam menyajikan informasi kebijakan pemerintah kepada masyarakat.

Akan tetapi bukan hanya terkait permasalahan ekonomi, rupanya indonesiabaik.id juga terlihat menyajikan isu-isu yang berkenaan dengan kepentingan politis, di mana isu-isu politik juga menjadi salah satu bagian yang dinilai berpotensi dalam upaya pemenangan pemilihan umum (Pemilu) serta pemilihan presiden dan wakil presiden (Pilpres) tahun 2019. Isu politik dan ekonomi diyakini penulis menjadi isu seksi yang dijadikan oleh dua kubu calon presiden yakni pihak petahana Jokowi-Ma'ruf Amin yang mewakili pemerintah berhadapan dengan calon presiden Prabowo dan calon wakil presiden Sandiaga Uno dalam memenangkan pertarungan dalam Pilpres 2019. Bila melihat posisi indonesiabaik.id sebagai media yang berada di bawah naungan pemerintah menjadikan posisinya dikaitkan sebagai corong pemerintah yang dinilai memiliki keberpihakan pada pihak petahana. Praktik kuasa kemudian diperlihatkan melalui produksi berita di media siber ini yang dinilai lebih menguntungkan pemerintah.

Dalam pandangan ekonomi politik instrumentalis, media merupakan instrumen pemilik media. Arah isi media akan ditentukan oleh pemilik media. Berdasarkan perpektif tersebut maka apa yang tersaji dalam media tersebut merupakan representasi dari seorang pemilik akan menyebabkan perubahan isi konten media. Jika pemilik media berafiliasi pada satu kekuatan tertentu maka isinya akan koheren dengan kekuatan politik tersebut. Dalam konteks ini, peneliti menilai fenomena tersebut terjadi di indonesiabaik.id.

Dari latar belakang penelitian tadi, maka masalah pokok penelitian ini menghasilkan rumusan masalah dalam pertanyaan penelitian, yaitu: "Bagaimana relasi kuasa negara dapat mempengaruhi media siber indonesiabaik.id dalam memproduksi konten berita ekonomi dan politik selama masa kampanye pemilihan Presiden Republik Indonesia 2019?" Berdasarkan uraian latar belakang di atas, maka penelitian ini bertujuan untuk mengetahui dan mendeskripsikan dinamika kuasa negara dalam memproduksi konten politik dan ekonomi di media siber indonesiabaik.id menjelang pemilihan presiden (Pilpres) 2019.

\subsection{Tinjauan Pustaka}

\section{a) Kuasa Media dalam Praktik Kuasa Negara}

Penelitian ini berangkat dari permasalahan teoritis bawa media harusnya terbebas dari segala tekanan dan pengaruh pihak dalam maupun luar selain mengabdi kepada kepentingan publik. Namun fenomenanya masih ada pengaruh kuat pemilik modal terhadap produksi konten media.

Kata "power" yang melekat pada kata "media" dalam bahasa Indonesia dapat diartikan kuasa atau kekuasaan, atau dalam penelitian ini bisa disimpulkan sebagai kekuatan media yang melekat pada media. Kekuasaan merupakan sebuah relasi dan posisi para pihak yang melakukan relasi di mana salah satu pihak memiliki posisi lebih dominan dan memiliki kemampuan untuk mempengaruhi posisi yang didominasi. Bagi media, kuasa dalam pengertian ini bisa dikategorikan menjadi media memiliki kekuasaan atau kekuatan serta dalam media ada kuasa yang direpresentasikan (Rusadi, 2015). 
Menurut teori normatif, media memiliki hak dan tanggung jawab agar media bisa memberikan manfaat kepada individu dan masyarakat. Teori normatif melihat kekuasaan media dihubungkan dengan struktur kekuasaan di negara di mana media hidup. Kemudian Rusadi (2015) menyimpulkan ungkapan Siebert dkk bahwa sistem pers akan menyesuaikan dengan sistem politik di mana media itu berada, yaitu sistem otoriter, liberal, tanggung jawab sosial, dan komunis. Teori ini memiliki premis-premis yang salah satu di antaranya berdasarkan posisi hubungan media dengan pemerintah. Pola hubungan pemerintah dengan media pada sistem otoriter, menempatkan pemerintah yang mengendalikan struktur kekuasaannya. Artinya, pemerintah menggunakan media sebagai instrumen. Pemerintah juga memiliki kekuasaan untuk mengendalikan media. Pada sistem pers liberal, siapa yang memiliki kekuasaan adalah yang mengendalikan media. Pada sistem pers komunis, yang memiliki kekuasaan adalah partai komunis. Terakhir, dalam sistem pers tanggung jawab sosial, media adalah pihak yang bertanggung jawab secara sosial kepada publik.

Menurut Murdock dalam Gurevitch M, Bennett T (2005) bahwa kekuasaan media dijalankan bisa melalui kekuatan alokatif dan kekuasaan operasional. Kekuasaan alokatif ialah kekuasaan untuk mengatur dan menempatkan orang-orang dalam jabatan di media yang bisa mengendalikan media. Sedangkan kekuatan operasional ialah kekuatan untuk memproduksi dan mendistribusikan konten media. Kekuasaan alokatif lebih pada upaya mengatur posisi pengambil keputusan dalam jajaran media, dan penempatan posisi ini akan ikut mempengaruhi praktik kekuasaan, sebab penempatan seorang pengambil keputusan merupakan penempatan penjaga pintu (gate keeper) dalam produksi dan distribusi konten media. Peran pemilik media yang tidak terjun langsung mengendalikan media dapat ditempuh dengan memilih orang yang sejalan dengan kepentingan si pemilik media. Peranan penting posisi pengambil keputusan sebagai agen dalam menjalankan kekuasaan media kemudian menjadi saluran pihak luar dalam melakukan intervensi kekuasaan. Mereka bisa menempatkan orang yang sejalan dengan kepentingan mereka, pemerintah yang dalam sistem media otoritarian bisa memengaruhi media dengan cara menempatkan orang pemerintah dalam jajaran pimpinan operasional media. Kekuasan operasional ialah kekuasaan pimpinan operasional yang memiliki kewenangan memutuskan isi media, kekuasaan untuk melakukan tindakan. Mereka memiliki kekuasaan dalam menentukan substansi dan juga artikulasinya. Substansi apa saja yang bisa diproduksi dan kemana orientasinya, jika berkaitan dengan politik merupakan pilihan untuk melakukan pemihakan atau penolakan pada sikap politik tertentu dan jika berkaitan dengan hiburan kategori hiburan seperti apa yang bisa dipresentasikan.

Penguasaan yang dilakukan media bisa berupa penguasaan kapital ekonomi, kapital politik atau kapital budaya. Merujuk pada pandangan yang disimpulkan Rusadi (2015), dalam pandangan ekonomi politik instrumentalis, objek material adalah objek yang dikuasa, di mana media berusaha mengakumulasi kapital material. Tapi bagi para pernikir neo-Marxis, objek kekuasaan bisa kekuasan politik ideologi, sosial, dan budaya. Ditambahkan Rusadi dalam penjelasannya bahwa wujud kekuasaan politik dapat berupa dukungan pengakuan atau keterlibatan dalam tindakan politik yang sesuai dengan visi politik yang diusung media. Sementara kekuasaan sosial dapat digunakan untuk mengembangkan jejaring dan dukungan pada nilai-nilai sosial. Adapun media juga bisa memperjuangkan kapital budaya berupa penguasaan pada nilai-nilai budaya serta nilainilai ideologi yang ada dalam masyarakat. Dengan demikian, kekuasaan yang diusung oleh media dapat bersumber dari struktur dan aktor yang ada di dalam dan mengendalikan media, tetapi juga oleh berbagai bersumber dari kekuasaan dalam masyarakat, apakah itu kekuasaan ekonomi, politik, sosial maupun budaya.

Media memiliki kekuatan tawar-menawar terhadap sumber daya lain tanpa sumber informasi atau sumber-sumber konten media, namun pada kenyataannya media kehilangan kekuatannya. Chouldry dan Curran dalam Pahdepie (2014)) memandang situasi ini sebagai paradoks kekuatan 
media. Mereka berpendapat bahwa tampaknya media memiliki kekuatannya sendiri (untuk mengalirkan atau menyebarkan informasi). Tetapi dalam kenyataannya kekuatan tersebut didorong oleh alat kekuasaan lain seperti pemilik media atau bisa juga dari pihak pemerintah. Dalam pengertian ini, kekuatan media kemungkinan besar hanya ilusi. Tampaknya media memiliki kekuatan untuk mengintervensi atau mengendalikan konflik sosial. Tetapi dalam kenyataannya media hanyalah alat yang digunakan oleh sumber kekuasaan lain seperti kekuatan politik (pemerintah) atau kekuatan ekonomi (bisnis) untuk menengahi kepentingan mereka (Couldry \& Curran, 2003). Ditambahkan Chouldry dan Curran (2003), salah satu cara untuk mendefinisikan kekuatan media adalah melalui kekuatan tawar media yang independen, di mana kekuatan tawar media dinilai punya pengaruh signifikan terhadap sektor-sektor utama lainnya, seperti bisnis besar, elite politik, elite budaya, dan seterusnya. Hal ini tidak tampak langsung sampai seseorang menyadari bahwa media punya kekuatan tawar, misalnya atas pembingkaian cerita tertentu.

Di sini kita sampai pada inti paradoks yang jelas tentang kekuatan media, yang berasal dari fakta bahwa kekuatan tersebut menghadapi dua cara. Dari satu arah (arah analisis yang lebih umum) kekuatan media adalah istilah yang digunakan untuk menunjukkan bagaimana kekuatankekuatan lainnya menggunakan mekanisme media perantara. Contohnya seperti laporan pers, liputan televisi, situs web, dan sebagainya yang dipergunakan untuk melancarkan pertempuran mereka. Pertempuran media tersebut dapat dilihat melalui kekuatan korporasi melawan tenaga kerja, profesional lama dan elite kelas melawan elite budaya baru, dan sebagainya (Couldry, N., \& Curran, 2003).

\section{b) Relasi Kuasa dan Komunikasi Politik}

Kekuasaan terwujud dan dilembagakan melalui sistem politik termasuk melalui kebijakankebijakan pemerintah. Rousseau mengemukakan bahwa kekuasaan pemerintah berasal dari apa yang disebut kontrak sosial atau perjanjian sosial antara individu dalam masyarakat (Rousseau, 2012). Kontrak ini menciptakan hubungan khusus antara orang-orang yang mengatur (atau memerintah) dengan orang lain yang diatur (atau diperintah), situasi ini adalah apa yang disebut sebagai "power as a relation among people (kekuasaan sebagai hubungan di antara orangorang)"(Dahl, 1957). Kekuasaan adalah produksi efek dari sekelompok orang yang dilakukan guna mengendalikan sistem sosial (Barnett \& Duvall, 2005).

Relasi kuasa dalam media dapat jadi alat untuk melegitimasi kekuasaan dalam masyarakat dengan cara membingkai realitas dengan membangunnya (frame building) melalui proses produksi konten berita. Dalam komunikasi politik, pembingkaian didefinisikan dan dioperasionalkan berdasarkan konstruktivisme sosial. Media massa secara aktif menetapkan kerangka referensi yang digunakan pembaca dan pemirsa untuk menafsirkan dan mendiskusikan acara public seperti penjelasan Tuchman dalam Pan (1993).

Teori konstruksi realitas sosial sebagai basis membangun frame berita dikemukakan oleh Berger dan Luckman (1966) yang intinya menjelaskan bahwa proses sosial melalui tindakan dan interaksi individu secara intens menciptakan suatu realitas yang dimiliki dan dialami bersama secara subjektif, sebagai suatu pengetahuan melalui tahapan ekternalisasi, objektifikasi dan internalisasi. Realitas sosial sesungguhnya tidak lebih dari sekedar hasil konstruksi sosial dalam komunikasi tertentu (Sobur, 2001).

Dalam proses produksi berita wartawan bisa jadi mempunyai pandangan, dukungan, dan konsep yang berbeda ketika melihat suatu realitas. Hal itu dapat dilihat dari bagaimana para pekerja media satu dan lainnya memiliki perbedaan cara memberitakan karena mengkonstruksikan peristiwa yang diwujudkannya. Dari anggapan itulah, maka sangat potensial terjadi peristiwa yang sama dikonstruksi secara berbeda antara media yang satu dengan media yang lainnya karena 
adanya kepentingan-kepentingan yang dikonstruksikan melalui media massa sebagaimana diungkapkan Bungin (2011) bahwa konstruksi sosial tidak berlangsung dalam ruang hampa, namun sarat dengan kepentingan-kepentingan.

Hasil kontruksi realitas sosial tersebut merupakan frame berita. Gamson dan Modigliani dalam de Vreese (2005) secara konseptual mendefinisikan bingkai media sebagai "sebuah ide pengorganisasian pusat atau alur cerita yang memberikan makna pada serangkaian peristiwa yang sedang berlangsung, bingkai tersebut menunjukkan apa yang menjadi kontroversi, yang merupakan esensi dari permasalahan" (de Vreese, 2005). Bingkai media juga berfungsi sebagai rutinitas kerja bagi jurnalis yang memungkinkan jurnalis untuk dengan cepat mengidentifikasi dan mengklasifikasikan informasi dan "untuk mengemasnya agar disampaikan secara efisien ke audiens mereka" (Scheufele, 1999).

Dalam logika demokrasi, relasi kekuasaan ini selalu perlu diatur atau dibatasi. Dahl berpendapat bahwa untuk menahan hubungan semacam ini sering membutuhkan standar di mana seseorang dapat menilai yang lain seperti diuraikan Dahl dalam Gastil (2008). Selain itu, Gastil menawarkan tiga cara untuk menciptakan standar: (1) melalui komunikasi politik, (2) melalui partisipasi politik, dan (3) melalui rekrutmen politik. Ia percaya bahwa proses politik ini harus dilakukan berdasarkan prinsip etika deliberatif atau keterlibatan yang disengaja antara pemerintah dan publik. Berkenaan dengan hal ini, ia percaya bahwa semakin sering suatu sistem disengaja, semakin mudah ia dapat memenuhi tiga kriteria untuk proses politik yang demokratis (Gastil, 2008).

Istilah komunikasi politik penting untuk mengendalikan kekuatan politik dalam masyarakat karena dua alasan sebagaimana diungkapkan Norris seperti disimpulkan Pahdepie (2014) bahwa: Pertama, penting bagi pemerintah untuk menginformasikan dan mendidik masyarakat. Kedua, penting bagi publik untuk menyampaikan pendapat mereka kepada pemerintah. Melalui komunikasi, baik pemerintah dan publik dapat saling mengontrol untuk mencapai hubungan timbal balik dalam kesepakatan sosial. Komunikasi ini juga membatasi kekuatan pemerintah dan publik dalam sistem politik. Misalnya, ketika pemerintah memiliki program yang akan dijalankan untuk diwujudkan, program tersebut harus dikomunikasikan dengan baik kepada publik. Namun, dengan cara yang sama, publik juga harus mengendalikan cara pemerintah menjalankan program. Masyarakat perlu melacak program-program tersebut dalam hal akuntabilitas, tanggung jawab, dan transparansi pemerintah.

Komunikasi politik adalah bagian dari apa yang disebut relasi kekuasaan, hubungan antara pemerintah dan masyarakat tidak selalu timbal balik yang seimbang seperti dikatakan Dahl dalam Pahdepie (2014). Dahl percaya bahwa dalam hubungan semacam ini, akan selalu ada aktor yang lebih berpengaruh daripada yang lain, dan dalam hal hubungan kekuasaan, pemerintah akan memiliki kecenderungan untuk mendominasi rakyatnya (Dahl, 1957). Meskipun ada banyak kritik kepada Dahl mengenai ide ini, dalam hal hubungan politik, pemahaman pemerintah sebagai agen dominasi di lingkup publik masih dapat diterima. Bahkan di negara yang paling demokratis seperti Amerika Serikat, misalnya, tidak dapat dihindari bahwa pemerintah masih memegang kekuasaan lebih besar untuk memerintah rakyatnya demi mengejar kesejahteraan umum dan keamanan daripada sebaliknya (Pahdepie, 2014).

Dalam pengertian ini, kecenderungan pemerintah untuk mengendalikan atau memengaruhi rakyatnya dapat disimpulkan sebagai bentuk dominasi. Sementara dalam hal hubungan kekuasaan, mendominasi adalah memiliki kemampuan untuk mengendalikan dan mengintervensi aktor-aktor lain untuk melakukan sesuatu yang tidak dilakukan oleh para aktor lainnya. Selain itu, menurut Lovett (2010) dominasi hanya dapat terjadi dalam hubungan sosial yang melibatkan dua atau lebih aktor (individu atau kelompok). Lovett kemudian mendefinisikan dominasi dalam hal hubungan 
sosial, ketergantungan dan kekuasaan sewenang-wenang sebagai ketidakseimbangan, atau kadangkadang ketidakadilan, hubungan. Secara umum, berdasarkan definisi Lovett, pemerintah adalah agen yang lebih independen sementara publik adalah aktor yang lebih bergantung.

\section{METODE PENELITIAN}

Penelitian ini menggunakan paradigma konstruktivisme yang memandang realitas yang ada telah melalui proses konstruksi sebagaimana diungkapkan Denzin dan Lincoln (Denzin, N. K., \& Yvonna, 2009) mengenai konstruktivisme sebagai filsafat pengetahuan yang meyakini bahwa pengetahuan manusia merupakan hasil kostruksi dari manusia itu sendiri.

Pendekatan penelitian ini menggunakan pendekatan kualitatif dengan mengamati objek dalam fenomena penelitian untuk memahami dan mempelajari permasalahannya yang berhubungan dengan bahasa dan peristilahan dari aktor-aktor yang terlibat di dalamnya. Kirk dan Miller dalam Moleong (2011) menjelaskan bahwa penelitian kualitatif adalah tradisi tertentu dalam ilmu pengetahuan sosial yang secara fundamental bergantung pada pengamatan pada manusia dalam kawasannya sendiri dan berhubungan dengan orang-orang tersebut dalam bahasanya dan dalam peristilahannya.

Metode penelitian yang digunakan yakni studi kasus yang memusatkan diri secara intensif terhadap satu objek dengan cara mempelajarinya sebagai suatu kasus yang unik dan memiliki kekhasan sebagaimana diungkapkan Yin (2015) bahwa studi kasus adalah suatu inkuisi empiris yang menyelidiki fenomena di dalam konteks kehidupan nyata, bilamana batas-batas antara fenomena dan konteks tak tampak dengan tegas, dan di mana multisumber bukti dimanfaatkan.

Studi kasus pada penelitian ini mengacu pada keberadaan indonesiabaik.id sebagai media informasi siber di mana praktik kuasa berperan dalam membingkai isu politik dan ekonomi terkait dengan Pemilu Presiden 2019. Studi kasus ini digunakan untuk menunjukan pentingnya situs ini sebagai media yang dinilai dimanfaatkan penguasa dalam menunjukan dominasinya untuk dipelajari sebagai suatu kasus yang menurut. Yin (2015) menunjukan peran peneliti yang hanya memiliki peluang kecil sekali atau tidak mempunyai peluang sama sekali untuk melakukan kontrol terhadap peristiwa tersebut sehingga berupaya mengedepankan pertanyaan "bagaimana" dan "mengapa" guna diarahkan ke serangkaian peristiwa kontemporer yang diamati tersebut.

Penelitian ini menggunakan dua orang informan, yakni Dimas Aditya Nugraha selaku Kasubdit Audio Visual dan Media Sosial di Direktorat Pengelolaan Media Ditjen Informasi dan Komunikasi Publik Kemenkominfo Republik Indonesia sekaligus Pimpinan Redaksi dan Project Leader indonesiabaik.id; dan Uji Agung Santosa selaku Tenaga Ahli Dirjen IKP Kemenkominfo Republik Indonesia sekaligus editor situs ini. Keduanya dipilih secara purposif berkenaan dengan peran dan pengetahuannya dalam hal kebijakan produksi berita di media siber ini. Teknik pengumpulan data dilakukan melalui wawawancara, observasi, dan studi kepustakaan. Sedangkan uji keabsahan data dilakukan melalui teknik triangulasi sumber, di mana informasi dari berbagai sumber diperbandingkan satu sama lain sebagai cara untuk melakukan verifikasi informasi atas informasi dari berbagai sumber tersebut. 


\section{HASIL DAN PEMBAHASAN}

\subsection{Alur Produksi Konten indonesiabaik.id}

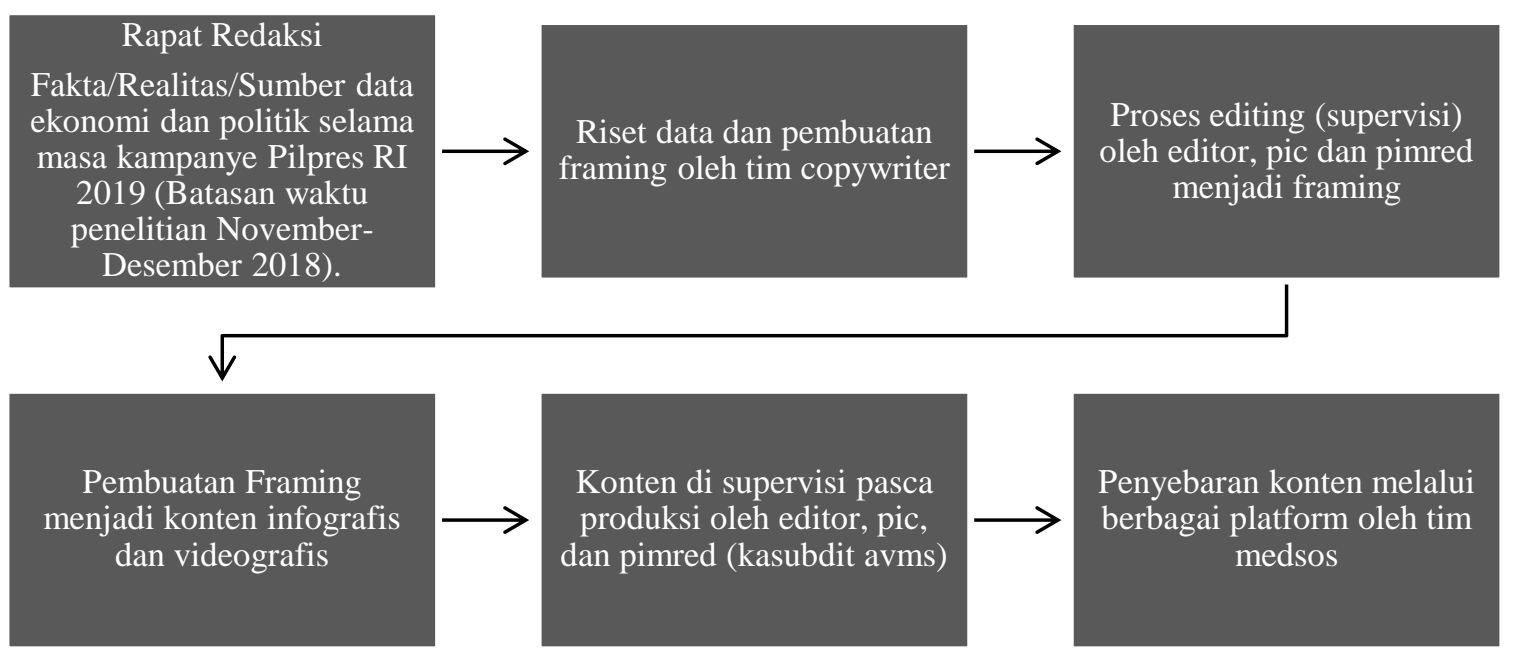

Sumber: Olahan peneliti, 2019.

Gambar 1. Bagan Alur Produksi Konten indonesiabaik.id

Dalam Bagan Alur Produksi Konten indonesiabaik.id yang diolah berdasarkan penelitian penulis, terlihat bagaimana cara redaksi media siber ini membangun bingkai mereka sejak awal. Dimulai dalam rapat redaksi, pimpinan redaksi yaitu Kasubdit Audio Visual dan Media Sosial Direktorat Pengelolaan Media Ditjen Informasi dan Komunikasi Publik Kementerian Komunikasi dan Informatika, dibantu pic (aparatur sipil negara Kemenkominfo) yang ditugaskan sebagai redaktur pelaksana, beserta editor (tenaga ahli) dan tim copywriter menggodok rencana produksi konten selama sepekan ke depan.

Rapat redaksi ini mengetengahkan agenda setting dari pemerintah untuk mendiseminasikan kebijakan dan program pemerintah apa yang ingin disampaikan kepada publik. Ada beberapa Kementerian/Lembaga (K/L) yang "memesan" pembuatan konten tertentu kepada tim indonesiabaik.id dalam rangka mensosialisasikan program/kebijakan mereka agar disebarluarkan kepada masyarakat, meski dalam frekuensi yang tidak banyak. Ini merupakan indikasi potensi kuasa negara dalam proses produksi berita atau konten sangat tinggi.

a) Cara Kuasa Negara Membangun Bingkai Isu Politik dan Ekonomi

Cara negara membangun bingkai isu politik dan ekonomi di media siber indonesiabaik.id menjelang Pemilu Presiden 2019 dilakukan melalui adanya intervensi yang dilakukan perangkat pemerintah yang terkait dengan nama petahana Jokowi-Ma'rif Amin. Intervensi ini utamanya dilakukan dengan memberikan data-data yang terkait dengan keberhasilan-keberhasilan pemerintah. Upaya intervensi tersebut lebih dilakukan secara halus dengan banyak menyodorkan data-data yang dinilai "menguntungkan pemerintah" melalui konten-konten berita positif sebagaimana diungkapkan Tenaga Ahli Dirjen IKP Kemenkominfo Republik Indonesia sekaligus editor situs ini mengenai adanya intervensi dari pihak pemerintah, bahwa:

"Intervensi ada, cuma sebagai tenaga ahli harus pandai-pandai mengetahui celah yang bisa dipakai agar bisa mewadahi setiap kepentingan. Untuk intervensi konten politik, selama ini 
tidak banyak terjadi, yang ada adalah permintaan untuk memperbanyak konten-konten positif tentang petahana." (Keterangan Uji Agung Santosa dalam wawancara, 14 Desember 2018).

Pada dasarnya konten indonesiabaik.id yang memang banyak berisi mengenai segala bentuk pencapaian program pemerintah lebih banyak menyampaikan konten-konten positif. Pemerintah sebenarnya sadar betul bahwa nama situs ini yang berada di bawah naungan Kemenkominfo mau tidak mau akan berkaitan dengan segala bentuk pemberitaan program pemerintah. Adanya intervensi untuk lebih memperbanyak konten positif tentang petahana (pasangan Jokowi-Ma'ruf Amin) semakin melegitimasi bahwa adanya pengerahan upaya memanfaatan media pemerintah sebagai corong utama pemerintah.

Jika dilihat dari pemanfaatan dan keberadaannya, sebenarnya pemerintah tidak perlu mengeluarkan tenaga besar untuk memanfaatkan indonesiabaik.id sebagai media yang lebih menguntungkan pihak petahana dengan pemberitaan yang memang berisi mengenai programprogram pemerintah. Intervensi pihak pemerintah yang seakan meminta porsi lebih dalam hal produksi konten yang dinilai menguntungkan pihak petahana justru terlihat memaksakan dan melegitimasi keberadaan situs ini sebagai bagian dari tangan pemerintah meskipun pada tujuan awalnya tidak ditujukan seperti itu. Terlebih intervensi tersebut juga telah masuk pada wilayah pembuatan konten seperti halnya dalam pembuatan judul pemberitaan yang diungkapkan Kasubdit Audio Visual dan Media Sosial di Ditjen IKP Kemenkominfo Republik Indonesia sekaligus Pimpinan Redaksi dan Project Leader situs ini pernah mengalami adanya tekanan dalam membuat konten bermuatan hard campaign, bahwa:

"Kami pernah mendapatkan tekanan dari atasan (dengan mengatasnamakan kantor staf presiden) untuk membuat konten dengan pembingkaian "hard campaign" namun kami menolaknya dengan halus dan menawarkan membangun bingkainya pembuatan konten tersebut dari sisi lain agar lebih menarik dibaca oleh publik. Dari sisi penyebutan presiden pun, kami berusaha tidak menyingkat menjadi Presiden Jokowi tetapi mengedepankan nama lengkap yaitu Presiden Joko Widodo atau disandingkan dengan Wakil Presiden Jusuf Kalla atau bahkan hanya kami sebutkan peleburannya dalam kata pemerintah saja." (Keterangan Dimas Aditya Nugraha dalam wawancara, 12 Desember 2018).

Intervensi penguasa yang dilakukan pihak dengan mengatasnamakan pemerintah kemudian berlanjut bukan hanya pada adanya usulan atau dorongan untuk memberitakan konten positif saja, tetapi juga mulai masuk pada kebijakan penentuan konten pemberitaan. Salah satunya terlihat dari adanya "tekanan" yang diterima pihak indonesiabaik.id untuk melakukan pembingkaian berkonsep hard campaign yang menguntungkan pihak petahana. Hard campaign ini dapat berupa apa saja seperti halnya pemilihan judul yang lebih menguntungkan petahana, pemilihan istilah kata maupun visual infografis yang lebih menguntungkan petahana, hingga pemilihan isu yang dinilai sesuai untuk menaikan nama petahana. Seperti halnya pada kasus pemberitaan mengenai pelarangan HTI (Hizbut Tahrir Indonesia) yang dilarang di bawah kepemimpinan Presiden Joko Widodo, produksi konten tersebut tidak lantas disajikan dalam muatan hard campaign namun dari sisi lain yang lebih diperhalus (soft campaign) tanpa menghilangkan substansi yang ingin disampaikan oleh pemerintah kepada publik, bahwa:

"Kami pernah membuat beberapa konten yang terkait dengan pelarangan HTI. Namun cara kami membangun bingkai dalam produksi konten tersebut mengambil dari sisi lain seperti dalam judul "Hati-hati Perang Proxy" lalu kepada substansi "bagaimana cara menjaga kesatuan NKRI" bukan langsung kepada substansi "hard campaign" yang lebih "tajam". Mengapa kami harus seperti itu? Karena kami harus tetap konsisten kepada brand yang 
sudah kami bangun. Jika tidak bertahan seperti itu dan memilih mengubah membangun bingkai konten ke substansi yang "hard campaign" maka brand kami sangat berpotensi tercemar dan publik akan melihat brand kami telah kami rusak sendiri. Untuk itu kami sangat berhati-hati dalam setiap membangun bingkai konten yang berkaitan dengan isu ekonomi maupun politik yang berpotensi ke arah "hard campaign" pemerintah." (Keterangan Dimas Aditya Nugraha dalam wawancara, 12 Desember 2018).

Tekanan untuk pihak indonesiabaik.id melakukan hard campaign yang menguntungkan pihak petahana merupakan salah satu bagian dari bentuk kekuasaan yang turut menentukan sikap media. Fakta yang disajikan melalui upaya pemberitaan yang secara langsung menguntungkan salah satu pihak, dinilai pihak redaksi akan menjadikan nama media siber ini menjadi tidak sehat dan hanya akan merusak citra dari situs ini sebagai media yang sebisa mungkin menjaga independensinya sebagai sumber informasi publik.

Cara pemerintah yang membingkai isu melalui pemberitaan yang bersifat hard campaign tersebut menjadi salah satu cara yang dinilai membebani independensi kepada media siber ini sebagai media yang dibangun atas nama keterbukaan dan netralitas. Di samping itu, kuasa negara atas indonesiabaik.id juga diperlihatkan melalui adanya bentuk supervisi birokrasi yang lama. Pemberitaan bukan hanya menyajikan fakta, tetapi juga aktualitas yang ternyata tidak dapat diberikan oleh media siber ini karena adanya supervisi yang berjenjang pada tingkat atas yang menunjukan khas birokrasi yang rumit. Setiap pemberitaan situs ini akan mendapatkan supervisi di tingkat atas yang menunjukan juga bahwa setiap konten yang disajikan seakan melalui persetujuan pemerintah yang dinilai melakukan pemilahan pemberitaan hanya pada yang dinilai menguntungkan pihaknya:

"Pertama yang dilakukan adalah bagaimana data atau produk yang keluar, bisa dipercaya dan akurat. Sebab karakter birokrasi, memberi batas-batas psikologis yang membuat kita semakin aware dengan akurasi data dan validitas sumber. Bahkan dahulu di awal-awal konten dibuat, setiap produk yang keluar harus mendapatkan supervisi di tingkat lebih tinggi. Supervisi yang lama membuat Indonesiabaik tidak agile. Dan setelah kita mendapatkan kepercayaan, maka supervisi menjadi hanya di tingkat tenaga ahli saja. Setelah validitas dan akurasi data diperoleh, baru kemudian membingkai data dalam satu framing yang kuat. Judul-judul bombastis dan provokatif tidak bisa dipakai. Apalagi netralitas ASN secara jelas tidak diperkenankan untuk mendukung calon tertentu atau berpolitik." (Keterangan Uji Agung Santosa dalam wawancara, 14 Desember 2018).

Faktualitas yang terjaga ternyata tidak diimbangi aktualitas berita yang mumpuni, meskipun sekarang ini mengalami perbaikan dalam hal aktualitas pemberitaan dengan supervisi yang lebih sederhana untuk beberapa jenis pemberitaan. Salah satu contohnya pada konten berjudul "Ini Tiga Dasar dikeluarkannya Perppu" di mana konten ini baru diunggah beberapa hari setelah Perppu Nomor 2 Tahun 2017 dirilis oleh pemerintah. Konten ini pula yang dinyatakan oleh pimred indonesiabaik.id memiliki kandungan soft campaign atau mengkampanyekan program dan kebijakan pemerintah secara halus tanpa menghilangkan substansi dari apa yang ingin disebarluaskan oleh pemerintah. 


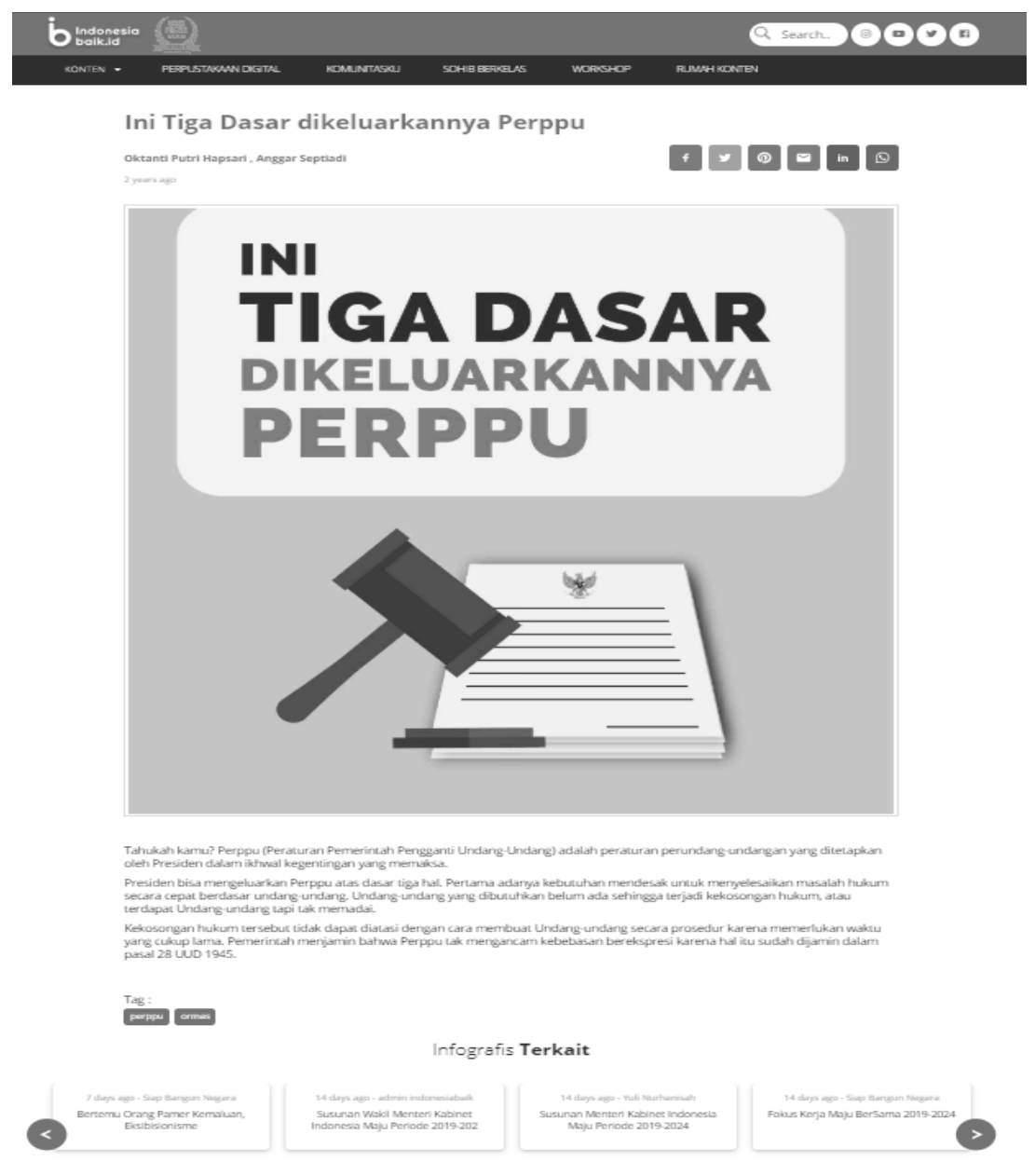

Sumber: indonesiabaik.id (Diakses tgl. 11/12/2018)

Gambar 2. Konten soft campaign indonesiabaik.id berjudul "Ini Tiga Dasar Dikeluarkannya Perppu"

Pada bagian ini memperlihatkan bahwa pemerintah dinilai penulis seakan melakukan supervisi pada berita-berita yang sebenarnya telah ada datanya dari pihak pemerintah itu sendiri. Hal ini dinilai sebagai indikasi kekhawatiran dari pihak pemerintah mengenai adanya kemungkinan pemberitaan yang tidak sesuai atau tidak menguntungkan salah satu pihak yang dalam hal ini ditujukan pada petahana. Kuasa pemerintah atas indonesiabaik.id pun kemudian ditunjukan melalui serangkaian ketentuan birokrasi yang justru menghambat aktualitas pemberitaan yang seharusnya dapat ditampilkan dengan lebih aktual. Kuasa negara kemudian menunjukan perannya untuk kembali melakukan mengawasan secara berlebihan pada semua produk jurnalistik situs ini dengan melakukan penyortiran pemberitaan yang dinilai hanya akan tayang jika dinilai aman untuk nama baik petahana.

\section{b) Peran Media dalam Relasi Kuasa}

Peran indonesiabaik.id dalam relasi kuasa menjelang Pemilu Presiden 2019 dilakukan dengan menjadikan media ini untuk membuka dialog publik. Melalui isu yang diangkat, media siber ini menyajikan fakta-fakta versi pemerintah dengan didukung data resmi yang dijadikan sebagai cara untuk menghalau informasi yang tidak tepat di luar sana. Pun data serta fakta dari pemerintah mampu membuka ruang dalam membangun opini publik melalui dialog yang akan terbangun di dalamnya. 
Situs ini menempatkan diri sebagai media yang sebisa mungkin menunjukan netralitasnya sebagai media dengan menyajikan data-data dalam versi pemerintah. Akan tetapi bentuk netralitas tersebut bagaimana pun juga akan menjadi bias di kala indonesiabaik.id mengidentifikasi dirinya sebagai bagian dari pemerintah atau produk yang dibuat dari kebijakan pemerintah. Di luar dari netralitas yang dipertanyakan, media siber ini pada dasarnya berperan dalam membuka dialog dari berbagai pihak baik itu oposisi maupun pemerintah dalam mendiskusikan berbagai data yang ada tanpa bermaksud terseret dalam kepentingan politik praktis.

"Dengan garis besar haluan redaksi yang jadi tujuan pembentukan media ini, kami berusaha menampilkan sisi lain dari sebuah isu ekonomi dan politik yang kami nilai berpotensi menjadi perdebatan publik khususnya dari kubu oposisi. Pastinya kami berusaha agar tidak terseretseret dalam komunikasi politik yang memiliki irisan di politik kenegaraan dan politik praktis. Kami tidak mau masuk ke bagian itu, karena inti dari tujuan www.indonesiabaik.id adalah komunikasi publik." (Keterangan Dimas Aditya Nugraha dalam wawancara, 12 Desember 2018).

Peran utama yang diperlihatkan indonesiabaik.id pada dasarnya menunjukan posisinya sebagai media yang mencoba bersikap netral di balik nama pemerintah yang rasanya memang sulit untuk ditanggalkan netralitasnya tersebut. Poin penting dari keberadaan media siber ini yakni adanya upaya untuk menjadikan pemberitaan yang diberikan sebagai media untuk membuka opini publik dan menjadikan media ini sebagai wadah dalam mendiskusikan berbagai data-data yang dimiliki pemerintah terkait dengan berbagai kebijakan yang diberikan.

Nama pemerintah bagaimanapun akan tetap melekat di balik nama situs ini karena mau tidak mau keberadaan situs ini memang utamanya dijadikan sebagai media komunikasi publik yang lahir atas kebijakan pemerintah. Dalam sambutannya saat peluncuran situs ini, Menkominfo 2014-2019, Rudiantara, mengatakan bahwa indonesiabaik.id merupakan salah satu kanal yang disediakan oleh Kementerian Kominfo untuk menyampaikan informasi tentang ragam program pemerintah dengan kemasan yang lebih menarik.

Perannya dalam membuka diskursus-diskursus lanjutan terkait dengan kebijakan pemerintah serta penyajian datanya yang dapat diakses secara terbuka dapat menjadi sumber informasi publik yang dapat digunakan dalam membuka dialog dan diskusi publik lanjutan terkait dengan kebijakankebijakan pemerintah dan pelaksanaannya di lapangan. Peran indonesiabaik.id kemudian juga menjadi media validasi atas informasi-informasi yang diterima publik dapat memberikan kesempatan bagi siapa saja termasuk oposisi untuk beradu argumentasi mengenai validitas data. Media siber ini menampilkan diri sebagai wadah publik yang berpeluang besar dalam membangun dialog publik sebagaimana diungkapkan Tenaga Ahli Dirjen IKP Kemenkominfo Republik Indonesia sekaligus editor situs ini, bahwa:

"Intinya setiap komentar seharusnya ditanggapi baik atau buruk. Jika kemudian kubu oposisi berkomentar negatif, maka itu seharusnya menjadi kesempatan untuk menjelaskan, bukan kemudian debat kusir." (Keterangan Uji Agung Santosa dalam wawancara, 14 Desember 2018).

Peran indonesiabaik.id dalam membuka ruang diskusi publik dengan menyajikan informasiinformasi dengan data yang berasal dari pemerintah sebenarnya menguatkan posisinya sebagai bagian dari humas pemerintah. Bukan berarti bahwa media siber ini menunjukan netralitas dengan tidak menyajikan data yang berasal dari pemerintah, karena pada kenyataannya data-data yang diperoleh situs ini berasal dari pemerintah sehingga juga apa yang disajikan dalam media siber ini mau tidak mau akan menguntungkan pemerintah. Diskusi publik yang dapat terbentuk dalam situs 
ini akan berhaluan pada kepentingan pemerintah karena data yang disajikan serta perannya dalam menyajikan data valid versi pemerintah menunjukan perannya sebagai media pemerintah yang meskipun diperhalus dengan mengedepankan netralitas, tetap saja nilai-nilai kuasa ada di dalamnya.

Tendensi indonesiabaik.id sebagai bagian dari pemerintah memang tidak dapat ditanggalkan, terlebih juga situs ini menyediakan data-data yang berasal dari kubu pemerintah untuk menghalau data-data yang berseberangan seperti halnya ketika ada data dari pihak oposisi.

"Bagi kami, komentar negatif dari kubu oposisi justru sangat positif dari sisi perkembangan pembaca. Kami sendiri memberi jawaban kepada mereka melalui berbagai platform media sosial bahwa kami hanya menampilkan data resmi yang telah dirilis oleh pemerintah dan dikemas ulang dalam bentuk infografis serta artikel untuk diketahui oleh publik, bukannya secara pemaknaan ditujukan untuk memuji pemerintah. Perlu diketahui bahwa mengolah data resmi pemerintah dan dikemas ulang itu tidak mudah. Terkadang ada beberapa instansi (kementerian/lembaga) yang saling tuding bahwa data yang dikeluarkan oleh salah satu instansi tidak valid. Disinilah terlihat ada level pentingnya data pemerintah keluar melalui satu pintu." (Keterangan Dimas Aditya Nugraha dalam wawancara, 12 Desember 2018).

Peran indonesiabaik.id yang membuka dialog publik dengan menyajikan data dari versi pemerintah menunjukan bahwa dialog yang dibangun dari media siber ini pada dasarnya akan mengedepankan nama pemerintah. Meskipun situs ini menjaga independensi serta menunjukan netralitas dan upaya untuk memisahkan diri dari kepentingan politik praktis, pada kenyataannya perannya sebagai media yang menyajikan data-data versi pemerintah tentu melegitimasi perannya sebagai media pemerintah. Suka atau tidak suka, situs ini mengedepankan bias independendensi media karena bagaimanapun juga semua bentuk penghalauan data yang tidak sesuai dengan data pemerintah akan dilakukan media siber ini dengan mengacu pada data yang berasal dari internal pemerintah.

\section{PENUTUP}

Berdasarkan pembahasan di atas, maka dapat disimpulkan beberapa poin bahwa cara kuasa negara dalam memproduksi konten isu politik dan ekonomi di media siber indonesiabaik.id menjelang Pemilu dan Pilpres 2019 dilakukan melalui adanya intervensi untuk lebih banyak memberitakan berita dengan muatan konten positif, melakukan tekanan pada pihak redaksi untuk membuat konten bermuatan hard campaign serta supervisi berjenjang sehingga aktualitas berita tersingkirkan karena adanya penyesuaian dengan kebutuhan pemerintah.

Peran indonesiabaik.id dalam relasi kuasa menjelang Pemilu dan Pilpres 2019 yakni ruang dalam membangun opini publik melalui dialog yang terbangun di dalamnya. Perannya juga dilakukan dengan menyajikan fakta-fakta valid versi pemerintah sehingga membangun opini publik yang berhaluan pada pemerintah. Berdasarkan pembahasan sebagaimana telah dipaparkan di atas, maka ada beberapa saran yang dapat penulis sampaikan untuk dapat didiskusikan, antara lain bagi masyarakat khususnya pembaca indonesiabaik.id sebaiknya melakukan perbandingan informasi dari berbagai sumber sebagai upaya verifikasi (crosscheck) pemberitaan atas segala informasi yang diterima.

Sebaiknya pihak pemerintah memberikan keleluasaan yang lebih besar pada pihak redaksional situs ini untuk dapat membuat konten pemberitaan yang variatif dan bukan hanya menguntungkan pemerintah saja, karena pada dasarnya pemerintah tetap akan diuntungkan melalui pemberitaan tersebut jika dapat melakukan verifikasi atas informasi yang disajikan. Sebaiknya supervisi konten 
situs ini dilakukan di tingkat internal redaksional saja untuk menjaga independensi sebagai media informasi publik.

\section{Ucapan Terima Kasih}

Penulis menyampaikan ucapan terima kasih kepada pihak-pihak yang telah berkontribusi dalam penyelesaian penelitian ini, antara lain yaitu: Bapak Dimas Aditya Nugraha (Kasubdit AVMS Direktorat Pengelolaan Media Ditjen IKP Kemenkominfo) selaku Pimpinan Redaksi indonesiabaik.id. Lalu, Bapak Uji Agung Santosa selaku Tenaga Ahli Subdit AVMS Ditjen IKP Kemenkominfo di indonesiabaik.id. Berikutnya, Bapak Marudur dan Ibu Vience Rumata selaku pengurus serta editor di Jurnal Studi Komunikasi Media Kemenkominfo. Kemudian Bapak Udi Rusadi selaku pembimbing penulis.

\section{DAFTAR PUSTAKA}

Barnett, M., \& Duvall, R. (2005). Power in International Politics. International Organization, 59(1), 39-75. https://doi.org/10.1017/S0020818305050010

Berger, P. L., Luckmann, T., \& Zifonun, D. (1966). The Social Construction of Reality. Penguin Books.

Bungin, B. (2011). Konstruksi Sosial Media Massa: Kekuatan Pengaruh Media Massa, Iklan Televisi dan Keputusan Konsumen serta Kritik Terhadap Peter L. Berger \& Thomas Luckmann. Kencana.

Couldry, N., \& Curran, J. (2003). Contesting Media Power: Alternative Media in a Networked World. Rowman \& Littlefield.

D’Angelo, P. (2002). News Framing as a Multiparadigmatic Research Program: A Response to Entman. Journal of Communication, 52(4), 870-888.

Dahl, R. A. (1957). The Concept of Power. Journal of Behavioral Science, 2(3), 201-215.

de Vreese, C. (2005). News Framing: Theory and typology. Information Design Journal \& Document Design, 13(1), 51-62.

Denzin, N. K., \& Yvonna, S. L. (2009). Handbook of Qualitative Research. Pustaka Pelajar.

Eriyanto. (2008). Analisis Wacana: Pengantar Analisis Teks Media. LKiS.

Fanani, F. (2016). Analisis Kebijakan Redaksional Harian Republika pada Pemberitaan Religio-Politik Masa Kampanye Presiden Tahun 2009. Jurnal The Messenger, 3(2), 48-68.

Gastil, J. (2008). Political Communication and Deliberation. Sage Publishing.

Gurevitch M, Bennett T, C. J. and W. J. (Ed.). (2005). Culture, society and the media (2005th ed.). Taylor \& Francis e-Library.

Herman, E. S., \& Chomsky, N. (1988). Manufacturing Consent: A Propaganda Model. Pantheon Books.

Kohut, A. (2008). The Politics of News: The News of Politics. 190-207.

Kominfo.go.id. (2017). Menkominfo Luncurkan Situs indonesiabaik.id. 6th June. https://kominfo.go.id/content/detail/9843/menkominfo-luncurkan-situs-indonesiabaikid/0/berita_satker

Kriesi, H. (2004). Comparing Political Communication: Theories, Cases, and Challenges. Cambridge University Press.

Lovett, F. (2010). A General Theory of Domination and Justice. Oxford University Press.

McCombs, M. E. (2004). Setting the Agenda: The Mass Media and Public Opinion. Polity Press.

McQuail, D. (2006). McQuail's Mass Communication Theory (5th ed.). Sage Publication.

Moleong, L. J. (2011). Metodologi Penelitian Kualitatif: Edisi Revisi (Cet. keduapuluhsembilan).

Pahdepie, F. (2014). Media as the Battleground for Politics: The Relation Between Politicians and Media Barons in Indonesian Politics. International Journal of Nusantara Islam, 2(2), 1-10.

Pan, Z. (1993). Framing Analysis: An Approach to News Discourse. Political Communication, 10(1), 55-75.

Rousseau, J. J. (2012). Of The Social Contract and Other Political Writings. Penguin.

Rusadi, U. (2015). Kuasa Media dalam Masyarakat: Sebuah Kerangka Teoritik. Jurnal Mediakom, 12, 1324.

Scheufele, D. (1999). Framing as a Theory Media Effect. Journal of Communication, 49(1), 103-122.

Sobur, A. (2001). Analisis Teks Media: Suatu Pengantar untuk Analisis Wacana, Analisis Semiotik, dan 
Analisis Framing. Remaja Rosdakarya.

Yin, R. K. (2015). Studi Kasus: Desain dan Metode. PT Rajagrafindo Persada.

Yüksel, Y. (2013). An Analysis of the Media and Government Relationship. Selçuk İletişim, 8(1), 57-70. 